\title{
Retraction Note to: MicroRNA-330-3p promotes cell invasion and metastasis in non-small cell lung cancer through GRIA3 by activating MAPK/ERK signaling pathway
}

Chun-Hua Wei ${ }^{1}$, Gang Wu' ${ }^{1}$ Qian Cai ${ }^{1}$, Xi-Can Gao ${ }^{1}$, Fan Tong ${ }^{1}$, Rui Zhou ${ }^{1}$, Rui-Guang Zhang ${ }^{1}$, Ji-Hua Dong ${ }^{2}$, Yu Hu${ }^{3}$ and Xiao- Rong Dong ${ }^{1^{*}}$

\section{Retraction Note to: \\ Journal of Hematology \& Oncology (2017) 10:125 \\ https://doi.org/10.1186/s13045-017-0493-0}

In accordance with the guidelines published by COPE, the authors have retracted this article [1] because of significant concerns regarding a number of Figures presented in this work. In Fig. 3C and 3D there are duplications in the NC and NC-LV groups in the $\mathrm{H} 460$ cells, NC-LV, OE-miR-330-3p-LV and anti-miR-330-3p-LV groups in the H1975 cells. In Fig. 7D, the H1975/NC-LV Vec image has been duplicated from the H460/NC image in Fig. 3C. There are multiple duplications throughout Fig. 6, and there are duplications in Fig. 9D (OE-miR330-3p-LV and OE-miR-330-3p-LV + U0126 groups in the H460 cells, OE-miR-330-3p-LV group in the H1975 cells). The data reported in this article are therefore unreliable.

All authors agree to this retraction.

\section{Open Access}

This article is distributed under the terms of the Creative Commons Attribution 4.0 International License (http://creativecommons.org/licenses/by/4.0/), which permits unrestricted use, distribution, and reproduction in any medium, provided you give appropriate credit to the original author(s) and the source, provide a link to the Creative Commons license, and indicate if changes were made.

\begin{abstract}
Author details
${ }^{1}$ Cancer Center, Union Hospital, Tongji Medical College, Huazhong University of Science and Technology, 1277 JieFang Avenue, Wuhan 430022, People's Republic of China. ${ }^{2}$ Experimental Center, Union Hospital, Tongji Medical College, Huazhong University of Science and Technology, 1277, JieFang Avenue, Wuhan 430022, People's Republic of China. ${ }^{3}$ Institute of Hematology, Union Hospital, Tongji Medical College, Huazhong University of Science and Technology, 1277 JieFang Avenue, Wuhan 430022, People's Republic of China.
\end{abstract}

Published online: 22 October 2020

Reference

1. Wei C, Wu G, Cai Q, et al. MicroRNA-330-3p promotes cell invasion and metastasis in non-small cell lung cancer through GRIA3 by activating MAPK/ERK signaling pathway. J Hematol Oncol. 2017;10:125. https://doi. org/10.1186/s13045-017-0493-0.

\section{Publisher's Note}

Springer Nature remains neutral with regard to jurisdictional claims in published maps and institutional affiliations.

\footnotetext{
*Correspondence: hustwhuh@126.com

${ }^{1}$ Cancer Center, Union Hospital, Tongii Medical College, Huazhong

University of Science and Technology, 1277 JieFang Avenue,

Wuhan 430022, People's Republic of China

Full list of author information is available at the end of the article
} permits use, sharing, adaptation, distribution and reproduction in any medium or format, as long as you give appropriate credit to the original author(s) and the source, provide a link to the Creative Commons licence, and indicate if changes were made. The images or other third party material in this article are included in the article's Creative Commons licence, unless indicated otherwise in a credit line to the material. If material is not included in the article's Creative Commons licence and your intended use is not permitted by statutory regulation or exceeds the permitted use, you will need to obtain permission directly from the copyright holder. To view a copy of this licence, visit http://creativecommons.org/licenses/by/4.0/. The Creative Commons Public Domain Dedication waiver (http://creativeco mmons.org/publicdomain/zero/1.0/) applies to the data made available in this article, unless otherwise stated in a credit line to the data. 